\title{
Strategi Anti Fraud dalam Pengelolaan Dana Desa
}

\author{
Agri Christy Poima ${ }^{*}$, Aprina Nugraheshty Hapsari ${ }^{2}$ \\ 1,2 Jurusan Akuntansi Fakultas Ekonomika dan Bisnis Universitas Kristen Satya Wacana
}

\section{A R T I C L E I N F O}

Article history:

Received 01 December 2019

Received in revised form

31 December 2019

Accepted 15 January 2020

Available online 26

February 2020

\section{Kata Kunci:}

Pengelolaan Dana Desa,

Fraud, Strategi Anti Fraud

Keywords:

Village Fund Management

Fraud, Anti-Fraud Strategy

\begin{abstract}
A B S T R A K
Peningkatan jumlah kucuran dana desa yang dilakukan pemerintah ternyata tidak sejalan dengan pengelolaan yang baik. Terbukti dengan ditemukannya beberapa kasus fraud dalam pengelolaan dana desa. Penelitian ini bertujuan untuk mengetahui potensi fraud dan strategi anti fraud dalam pengelolaan dana desa di Desa Karangtengah, Kecamatan Tuntang, Kabupaten Semarang. Penelitian ini merupakan penelitian deskriptif kualitatif. Sumber data dalam penelitian ini diperoleh dari data primer melalui wawancara mendalam dan dokumentasi. Teknik analisis yang digunakan yaitu reduksi data, penyajian data dan penarikan kesimpulan. Jenis fraud yang diteliti dalam penelitian ini adalah fraud dalam pelaporan keuangan. Hasil dalam penelitian ini menunjukkan bahwa tidak ditemukannya potensi fraud dalam pengelolaan dana desa karena adanya penerapan strategi anti fraud yang dilakukan di Desa Karangtengah.
\end{abstract}

\section{A B S T R A C T}

The increase in the amount of village funds disbursed by the government is apparently not in line with good management. Evidenced by the discovery of several cases of fraud in the management of village funds. This study aims to determine the potential for fraud and anti-fraud strategies in managing village funds in Karangtengah Village, Tuntang District, Semarang Regency. This research is a qualitative descriptive study. Sources of data in this study were obtained from primary data through in-depth interviews and documentation. The analysis techniques used were data reduction, data presentation and drawing conclusions. The type of fraud investigated in this study is fraud in financial reporting. The result of this research indicates that no potential fraud was found in the management of village funds due to the implementation of an anti-fraud strategy carried out in Karangtengah Village.

\footnotetext{
* Corresponding author.

E-mail addresses: 232015242@student.uksw,edu (Agri Christy Poima)
} 


\section{Pendahuluan}

Undang-Undang Nomor 6 tahun 2014 tentang desa (Pemerintah Republik Indonesia, 2014) telah memberikan kewenangan bagi desa untuk mengatur dan mengurus keseluruhan sumber pendapatan desa sebagai tanggung jawab desa dalam memenuhi kebutuhan dan prioritas desa. Dana desa bersumber dari APBN yang diperuntukkan bagi desa. Alokasi APBN untuk desa akan selalu meningkat dari tahun ke tahun (Tangkararo, Ilat dan Wokas, 2017). Dana desa yang dikucurkan oleh pemerintah di tahun 2015 sebesar Rp20,76 triliun, di tahun 2016 sebesar Rp49,98 triliun, di tahun 2017 sebesar Rp60 triliun dan di tahun 2018 sebesar Rp60 triliun. Jumlah anggaran dana desa yang cukup besar tersebut diharapkan dapat memajukan desa melalui peningkatan pelayanan publik, meningkatnya sumber daya desa dan desa tidak sekedar menjadi objek pembangunan tetapi juga menjadi subjek pembangunan.

Fenomena peningkatan jumlah kucuran dana desa yang dilakukan pemerintah ternyata tidak sejalan dengan pengelolaan yang baik. Terbukti dengan ditemukannya beberapa kasus fraud yaitu seorang kepala desa di Labuhan Tangga, Kecamatan Bangko, Kabupaten Rohil dituntut lima tahun penjara oleh Pengadilan Negeri Pekan Baru pada hari Selasa 28 November 2017 karena kasus korupsi dana desa sebesar Rp399 juta dalam APBD ditahun 2015 (Tanjung, 2017) dan kepala desa Dasuk kecamatan Pandemanu, Pamekasan, di Jawa Timur yang dituntut 2 tahun 6 bulan penjara karena memberikan uang suap sebesar Rp250 juta kepada Kepala Kejaksaan Negeri Pamekasan untuk menghentikan penyelidikan mengenai penyelewengan Alokasi Dana Desa untuk pemasangan paving dan pembuatan pagar kantor desa (Susanto, 2017). Kasus lainnya yaitu kepala desa Banjarsari, Kecamatan Jetis, di Mojokerto Jawa Timur yang ditetapkan sebagai tersangka kasus korupsi penyaluran Dana Desa dan Alokasi Dana Desa sebesar Rp487 juta pada tahun anggaran 2015 dengan modus pembangunan fiktif pavingiasi dan pembangunan gapura kantor desa (Widayat, 2018).

Sebelumnya telah banyak dilakukan penelitian terkait pengelolaan dana desa, khususnya dikaitkan dengan fenomena kecurangan. Hasil penelitian yang dilakukan oleh Atmadja, Adi dan Saputra (2015) menyatakan bahwa kompetensi aparatur dan sistem pengendalian internal berpengaruh signifikan terhadap pencegahan fraud dalam pengelolaan keuangan desa. Penelitian yang dilakukan oleh Wibisono dan Purnomo (2017) menunjukkan bahwa lemahnya unsur pembinaan dan pengawasan dari camat, Tim Pengawalan Pengamanan Pemerintahan dan Pembangunan (TP4), Badan Permusyawaratan Desa, dan kurangnya Sumber Daya Manusia (SDM) dalam pengelolaan dana desa dan kepala desa merupakan penyebab adanya kecenderungan penyalahgunaan dana desa. Seputro, Wahyuningsih dan Sunrowiyati (2017) juga melakukan penelitian mengenai potensi fraud dalam pengelolaan keuangan desa yang melihat potensi fraud dari sisi regulasi, tata kelola dan pengawasan.

Penelitian ini dilakukan untuk melihat potensi fraud dan strategi anti fraud dalam pengelolaan dana desa di desa Karangtengah, Kecamatan Tuntang, Kabupaten Semarang. Alasan pemilihan objek penelitian ini karena berdasarkan hasil wawancara awal dengan aparat desa Karang Tengah menyatakan bahwa adanya kenaikan dan penurunan harga-harga dalam perencanaan pengelolaan dana desa serta adanya staf aparat desa yang merangkap tugas karena masih kurangnya pemahaman dari aparat desa yang lain sehingga dalam pelaksanaan operasionalnya dimungkinkan terjadi penyelewengan dari pihakpihak pengelola. Selain itu di tahun 2018 Kabupaten Semarang mengalami penurunan dalam penerimaan dana desa (Rizqyana, 2018), sehingga fenomena ini menjadi menarik ketika dikaitkan dengan pengelolaan dana desa dan potensi kecurangannya.

Manfaat dari penelitian ini bagi desa Karangtengah adalah untuk memberikan evaluasi atau masukan terkait potensi fraud dan strategi anti fraud dalam pengelolaan dana desa. Penelitian ini juga bermanfaat bagi pemerintah dan akademisi. Manfaat penelitian ini bagi pemerintah adalah sebagai evaluasi yang akan menjadi masukan informasi kepada pemerintah terkait strategi anti fraud yang digunakan di desa Karangtengah untuk mengantisipasi adanya potensi fraud. Manfaat penelitian ini bagi akademisi adalah untuk menambah literatur tentang potensi fraud dalam pengelolaan dana desa.

Keuangan desa adalah semua hak dan kewajiban desa yang dapat dinilai dengan uang serta segala sesuatu berupa uang dan barang yang berhubungan dengan pelaksanaan hak dan kewajiban desa sebagaimana diartikan dalam Undang-Undang Nomor 6 tahun 2014 tentang Desa. Pengelolaan keuangan desa meliputi tahapan perencanaan, pelaksanaan, penatausahaan, pelaporan dan pertanggungjawaban.

Menurut Institute of Internal Auditor (IIA), fraud merupakan kecurangan yang disengaja atas tindakan yang tidak diijinkan dan melanggar hukum (Simbolon, 2010). Association of Certified Fraud Examiners (ACFE) mengklasifikasikan tindakan fraud menjadi tiga jenis yaitu fraud terhadap penyalahgunaan aset, fraud dalam laporan keuangan dan korupsi (Suryana dan Sadeli, 2015). Jenis fraud yang akan diteliti dalam penelitian ini terkait dengan penyalahgunaan dalam laporan keuangan. 


\section{Metode}

Penelitian ini adalah penelitian deskriptif kualitatif yang dilakukan di desa Karangtengah, Kecamatan Tuntang, Kabupaten Semarang. Narasumber dalam penelitian ini adalah aparat desa dan masyarakat desa Karang Tengah. Sumber data dalam penelitian ini berasal dari data primer yang diperoleh secara langsung melalui wawancara mendalam dengan aparat desa dan masyarakat desa Karang Tengah. Teknik pengumpulan data dilakukan dengan cara wawancara mendalam dengan narasumber dan dokumentasi. Wawancara mendalam dilakukan untuk mendapatkan informasi terkait potensi fraud dan strategi anti fraud dalam pengelolaan keuangan desa Karang Tengah. Sedangkan dokumentasi diperoleh dari dokumen-dokumen pendukung terkait pengelolaan dana desa.

Teknik analisis data dalam penelitian ini dilakukan melalui reduksi data, penyajian data dan penarikan kesimpulan. Dalam melakukan reduksi data, penyajian data maupun penarikan kesimpulan perlu diimbangi dengan teknik triangulasi. Triangulasi merupakan pengecekan yang dilakukan untuk mengetahui keabsahan data yang diperoleh dari wawancara maupun dokumentasi sehingga proses triangulasi perlu dilakukan dalam tahap reduksi data, penyajian data dan penarikan kesimpulan. Tahap pertama yang akan dilakukan dalam penelitian ini adalah mengumpulkan data primer yang diperoleh dengan melakukan wawancara dengan narasumber dan melakukan dokumentasi terkait dokumendokumen yang digunakan dalam pengelolaan keuangan desa seperti bukti transaksi, laporan keuangan dan dokumen pendukung lainnya. Hasil wawancara dari pertanyaan dan rekaman akan ditulis kembali, digolongkan dan menghapus data yang tidak perlu. Data yang diperoleh dari hasil wawancara maupun dokumentasi akan disusun kembali dan dianalisis sehingga memiliki makna tertentu untuk mencapai tujuan penelitian. Setelah penyajian data akan dilakukan penarikan kesimpulan dari data yang telah diperoleh.

\section{Hasil dan Pembahasan}

\section{A. Pengelolaan Dana Desa Karangtengah}

Tahapan perencanaan pengelolaan dana desa Karangtengah diawali dengan melakukan musyawarah dusun yang bertujuan untuk menentukan kebutuhan-kebutuhan di masing-masing dusun yang melibatkan perwakilan RT, RW, BPD dan tokoh-tokoh masyarakat yang terdapat di dusun tersebut. Tahap selanjutnya adalah melakukan musrenbangdes yang akan membahas mengenai skala prioritas di masing-masing dusun dan Rencana RPJMDes yang merupakan penjabaran dari visi misi kepala desa yang telah disusun sebelumnya. Berikut adalah hasil wawancara dengan beberapa narasumber sebagai aparat desa Karangtengah :

"Untuk musrenbangdes itu memang kita melibatkan semua masyarakat akan tetapi kadang-kadang setiap wilayah mewakilkan yang ditunjuk sesuai dengan keputusan musyawarah dusun. Kita sebelum masuk ke musrenbangdes kita musyawarah dusun dulu."(Bapak P selaku Kepala Desa, wawancara pada tanggal 4 April2019).

"Kan di desa dibentuk tim sebelas, tim sebelas itu mencari informasi dari dusun, didusun disana dikumpulkan masyarakat yang mau diusulkan ditahun ini apa aja yang prioritas apa jadi skala prioritas ditiap-tiap dusun apa gitu terus yang itu tugas tim sebelas masuk ke dusun-dusun mencari masukan informasi rencana pembangunan yang mau dilaksanakan setelah itu tim sebelas desa mengadakan musrenbangdes yang diikuti lembaga desa, tokoh masyarakat, tokoh agama, trus hasil musdus tadi dimasukan dirembuk didalam musrenbangdes."(bapak I selaku Sekretaris Desa, wawancara pada tanggal 23 April 2019).

“iya kan dari pertama kan RPJMdes itu penjabaran dari visi misi pak kepala desa."(Admin Desa, wawancara pada tanggal 5 Juli 2019).

Musrenbangdes dilakukan dengan melibatkan BPD, tokoh-tokoh masyarakat dan aparat desa yang akan menghasilkan Rencana Kerja Pembangunan Desa yang digunakan sebagai pedoman dalam penyusunan APBDesa. Hal ini sesuai dengan yang disampaikan oleh bapak M selaku kaur keuangan :

"Semua yang ada diAPBDes harus ada diRKP tidak boleh lepas dari itu harus ada duaduanya." (Wawancara pada tanggal 22 Juli 2019).

Pelaksanaan pencairan dana desa dilakukan melalui tiga tahap yaitu tahap pertama $20 \%$, tahap kedua $40 \%$ dan tahap ketiga sebesar $40 \%$ dengan persyaratan harus menyelesaikan terlebih dahulu surat pertanggungjawaban ditahap sebelumnya untuk melanjutkan ke tahap selanjutnya dengan jangka waktu 
kurang lebih empat bulan untuk setiap tahap. Jumlah dana desa yang diterima Desa Karangtengah untuk setiap tahunnya mengalami kenaikan yang digunakan untuk infrastruktur, gaji, operasional dan lembaga lainnya seperti karang taruna dan PKK. Hal ini sesuai dengan yang disampaikan oleh Bapak P selaku kepala desa :

"Pencairan 3 kali tahap, tahap pertama 20\% tahap kedua 40\% yang terakhir 40\%. Itu ada persyaratan yang pertama itu harus menyelesaikan dulu SPJ (Surat Pertanggungjawaban) yang pertama tahap pertama, lepas itu baru mencairkan tahap kedua. Kalo belum ada SPJ itu tidak bisa dicairkan tahap-tahap berikutnya." (Wawancara pada tanggal 4 April 2019).

Seluruh penerimaan dan pengeluaran desa dilakukan melalui rekening kas desa yang pencairan dananya ditandatangani oleh kepala desa dan bendahara desa sesuai dengan yang disampaikan oleh Bapak M selaku kaur keuangan desa :

"jadi gini kami bendahara memang selaku pengelola keuangan yang jelas semua sumber keuangan desa yang melalui dana transfer kan melalui kami jadi dibuku bank itu tercatatnya kan tidak mungkin hanya satu orang, jadi pemerintah desa atas nama kepala desa dan bendahara desa."(Wawancara pada tanggal 24 Mei 2019).

Tahapan penatausahaan keuangan desa dilakukan oleh bendahara desa dengan mencatat transaksi-transaksi keuangan yang terjadi dalam penerimaan maupun pengeluaran kas desa. Bendahara desa akan membuat buku kas umum, buku kas pembantu pajak dan buku bank. Pengelolaan keuangan desa dilakukan dengan membuat SPP (Surat Permohonan Permintaan) akan kebutuhan dari pelaksana kegiatan dan dana akan dicairkan berdasarkan SPP yang telah dibuat melalui rekening desa yang selanjutkan akan didistribusikan ke masing-masing pelaksana kegiatan dibidang pemerintahan, pembangunan, pembinaan dan pemberdayaan masyarakat. Hal ini sesuai dengan yang disampaikan oleh Bapak M selaku kaur keuangan desa :

"Pengelolaan kami setiap akan dicairkan membuat dokumen, membuat SPP dari pelaksana kegiatan masing-masing kasi kaur yang dikantor desa inikan buat, trus akhirnya saya mencairkan melalui bank BPD Jawa Tengah. Trus akhirnya setelah saya cairkan yah saya keluarkan sesuai SPP yang diberikan." (Wawancara pada tanggal 24 Mei 2019).

Dalam tahapan pelaporan dan pertanggungjawaban keuangan desa, pemerintah desa wajib memberikan laporan terkait penggunaan dana desa ke camat, bupati/walikota serta menyampaikan penggunaan dana desa yang telah digunakan kepada masyarakat. Laporan realisasi APBDes dibuat oleh sekretaris desa dan setiap tiga bulan sekali bendahara desa akan membuat laporan keuangan yang dilaporkan kepada kepala desa. Bentuk pelaporan juga dilakukan dengan memberikan informasi penggunaan dana kepada masyarakat, BPD, perangkat desa dan lembaga lainnya seperti karang taruna dan PKK dalam bentuk transparansi keuangan sesuai dengan yang disampaikan oleh Bapak P selaku kepala desa Karangtengah:

"Bentuk transparansinya kita menginformasikan langsung dana-dana yang masuk dan untuk kegiatan apa disampaikan ke masyarakat, kita informasikan melalui pertama BPD, melalui perangkat maupun lembaga yang lainnya mungkin karangtaruna atau PKK dan kita juga pasang papan nama dana. Betul-betul dana satu koma sekian itu untuk apa aja keliatan. Itu bentuk transparansi kita." (Wawancara pada tanggal 4 April 2019).

\section{B. Potensi Fraud dan Strategi Anti Fraud dalam Pengelolaan Keuangan Desa}

Potensi fraud yang diteliti di Desa Karangtengah adalah fraud terhadap laporan keuangan yang bisa terjadi karena adanya manipulasi, pemalsuan maupun pengubahan dalam penyusunan laporan keuangan. Hasil wawancara yang telah dilakukan menyatakan bahwa pengelolaan keuangan desa di Desa Karangtengah telah dilakukan sesuai dengan yang diharapkan oleh masyarakat desa dan pemerintah desa telah berusaha menjalankan dana desa sesuai dengan tujuan utamanya sehingga tidak ditemukan adanya potensi fraud dalam laporan keuangan. Selain itu, hal yang mendukung tidak ditemukannya potensi fraud dalam pengelolaan keuangan desa karena adanya penerapan strategi dalam mengurangi potensi fraud di Desa Karangtengah melalui pengawasan, penggunaan siskeudes, serta adanya kesadaran dari aparat desa dan masyarakat. Strategi yang pertama adalah adanya pengawasan keuangan desa yang dilakukan oleh instansi-instansi yang berwenang seperti yang disampaikan oleh Bapak M selaku kaur keuangan desa: 
"Yang mengawasi pengelolaan keuangan itu kan ada termasuk BPD mitra kerja, inspektorat, BPK, dispermades, dari kecamatan juga ikut membantu, ada TP4D (Tim Pengawal Pengamanan Pemerintah dan Pembangunan Daerah) dari kepolisian ada dari kerjaksaan ada kerjasama semua, saling membantulah, untuk menghindari hal-hal yang tidak diinginkan semua terlibat." (Wawancara pada tanggal 22 Juli 2019).

Pengawasan yang dilakukan oleh kecamatan berlangsung per semester dengan melakukan pemeriksanaan fisik dan memeriksa kesesuaian SPJ dengan pelaksanaannya. Sementara bentuk pengawasan yang dilakukan oleh inspektorat, dispermades maupun TP4D adalah dalam bentuk pembinaan untuk kelancaran dalam pelaporan dengan memeriksa langsung administrasi desa, SPJ dan laporan lainnya secara detail yang biasanya dilakukan secara mendadak tanpa ada pemberitahuan sebelumnya. Hal ini sesuai dengan yang disampaikan oleh operator siskeudes:

"Pengawasan itukan ada timnya mba, kayak inspektorat atau tp4d kesini kan ada timnya, ada yang ngoreksi siskeudesnya, spjnya, hasil fisiknya, hasil fisiknya sepertikan bangun jalan, jadi ada yang ngoreksi dibagian pelaporannya ada yang ngoreksi dilapangannya, jadi kesini tuh nggak cuman satu dua orang tapi rombongan dan kesininya tuh dadakan tanpa pemberitahuan."(Wawancara pada tanggal 19 Agustus 2019).

Selain pengawasan dari kecamatan maupun kabupaten, BPD juga melakukan pengawasan dengan memastikan kesesuaian belanja dan pengeluaran dengan RAB perencanaan serta hasil yang sudah dilaksanakan berdasarkan perencanaan. Selain itu, BPD juga memantau dalam pelaksanaan kegiatan dilokasi. Hal ini sesuai dengan yang disampaikan oleh beberapa perangkat desa:

"BPD juga kan ngawasi kalo itu pengeluaran dan pembelanjaan harus sesuai dengan RAB perencanaan dengan belanja."(Wawancara dengan kepala desa pada tanggal 4 April 2019).

"BPD laporannya cuman penyampaian hasil yang sudah dilaksanakan, sesuai diperencanaan itu yang sudah terlaksanakan."(Wawancara dengan kaur keuangan pada tanggal 22 Juli 2019).

Hal yang disampaikan tersebut juga sesuai dengan yang disampaikan oleh bapak AS selaku BPD desa Karangtengah :

"Kita juga memantau dari PK dan TPK itu, kita kira-kira dana segini terus biasanya gini mbak ada anggaran terus kita rencanakan contoh misalkan anggaran ini untuk apa terus sekian juta misalkan itu sudah seperti yang dianggarkan atau belum, selama pengerjaan kita juga ikut mengawasi."(Wawancara pada tanggal 14 Agustus 2019).

Strategi kedua yang dilakukan desa Karangtengah untuk mengurangi potensi fraud adalah melalui penerapan siskeudes. Pencatatan transaksi keuangan di Desa Karangtengah dilakukan secara manual dan terkomputerisasi. Pada pencatatan transaksi secara manual tidak menutup kemungkinan terjadi markup ataupun perubahan sehingga penerapan siskeudes dapat mengurangi resiko adanya fraud. Melalui siskeudes, kondisi keuangan desa dapat diketahui dengan adanya transaksi-transaksi keuangan yang tercatat disistem keuangan desa secara digital hal ini sesuai dengan keinginan pemerintah untuk menjadikan siskeudes sebagai sarana pengawasan yaitu untuk menghindari terjadinya manipulasi data secara manual. Pencatatan transaksi melalui siskeudes dilakukan secara real time, sesuai dengan yang disampaikan operator siskeudes desa Karangtengah:

"Langsung diisi, kita tanggalnya antara disiskeudes sama tanggal pengambilan dibuku bank harus sama."(Wawancara pada tanggal 19 Agustus 2019).

Perhitungan dalam transaksi di siskeudes sudah dilakukan secara otomatis sehingga dapat mengurangi adanya kesalahan dalam perhitungan, sesuai dengan yang disampaikan operator siskeudes:

"kayak belanja pegawai kita anggarkan segini realisasinya segini, ini udah otomatis."(Wawancara pada tanggal 19 Agustus 2019). 
Meskipun saat ini belum berbasis web, tetapi penerapan siskeudes membuat desa lebih tertata dan rapi dalam melakukan pencatatan transaksi keuangan. Hal ini sesuai dengan yang disampaikan operator siskeudes:

"Lebih tertata pengSPJan lebih enak, terus apa yah uang masuk itu langsung tercover digunakan untuk apa semuanya sudah tercatat disana kita tinggal masukan nominalnya".(Wawancara pada tanggal 5 Juli 2019).

Selain itu, ketika muncul kesalahan saat mengupload bukti transaksi ke dalam sistem keuangan desa admin siskeudes harus melampirkan berita acara yang dapat dijadikan sebagai sarana pengawasan seperti yang disampaikan oleh operator siskeudes:

"Kalo kita sudah posting gak bisa salah 100rupiah itu mau ada perubahan ada kesalahan yah kita untuk bilang kesana harus melampirkan berita acara kesalahan. Kalo bisa semaksimal mungkin kita harus sudah bener dulu, yakin bener gak ada kesalahan baru posting." (Wawancara pada tanggal 5 Juli 2019).

Selain pengawasan dan penerapan siskeudes, kesadaran aparat desa dan masyarakat juga merupakan salah satu strategi yang dilakukan untuk mengurangi potensi fraud dalam pengelolaan keuangan desa. Aparat desa selaku pengelola keuangan desa menginginkan untuk meningkatkan kesejahteraan dan pembangunan melalui dana desa dan memiliki kesadaran untuk mengelola dana desa sesuai dengan acuan ataupun peraturan yang berlaku. Hal ini sesuai dengan yang disampaikan oleh bapak I selaku sekretaris desa:

"Dana itu sekarang kan sudah dikasikan ke desa, dari pusat dikasikan ke desa untuk dikelola sesuai dengan aturan-aturan yang sudah ditentukkan terus itu memang bertujuan untuk kesejahteraan masyarakat untuk pembangunan, jadi yah kita sadar itu memang uang masyarakat jadi yah kita nggak berani macam-macam."(Wawancara pada tanggal 14 Agustus 2019).

Selain itu, aparat desa juga memiliki kesadaran untuk mengelola dana desa dengan sebaikbaiknya dan tidak memiliki keinginan untuk menyelewengkan dana desa. Hal ini sesuai dengan yang disampaikan oleh bapak I selaku sekretaris desa :

"Yah karena itu memang uang masyarakat, terus saya masih ingat betul saya menjadi perangkat desa juga disumpah disaksikan peserta disaksikan Tuhan yang maha esa juga apabila saya menyelewengkan uang itu untuk kepentingan pribadi yah saya kan otomatis melanggar sumpah saya, itukan mempertanggungjawabkan dunia akherat, yah saya ndak berani karena betul-betul itu uang masyarakat terus saya sendiri sudah dikasi honor sama pemerintah."(Wawancara pada tanggal 14 Agustus 2019)

Masyarakat juga berperan dalam pengawasan dengan terlibat secara langsung dalam pelaksanaan kegiatan pembangunan di desa. Selain itu masyarakat juga ikut berpartisipasi dalam musyawarah dengan BPD ataupun aparat desa serta pelaksana kegiatan akan menginformasikan anggaran yang digunakan dalam pembangunan desa. Masyarakat diperbolehkan mengetahui transparansi penggunaan dana desa melalui banner APBDes yang disediakan dikantor desa, papan dana untuk pembangunan yang disediakan disetiap dusun, maupun menanyakan secara langsung kepada aparat desa. Hal ini sesuai dengan yang disampaikan oleh bapak A selaku ketua RW di desa Karangtengah:

"Yah saya sendiri untuk itu kan sering ngecek juga, kira-kira kita dapat bantuannya misalnya jalan itu yang dibutuhkan apa, kan kita juga dikasi RABnya jadikan kita bisa kontrol juga, oh misalnya sekian juta itu untuk ini, misalnya beli semen sekian sak itukan kita juga bisa kontrol."(Wawancara pada tanggal 21 Agustus 2019).

\section{Simpulan dan Saran}

Secara umum, pengelolaan dana desa di Desa Karangtengah, Kecamatan Tuntang, Kabupaten Semarang sudah dilaksanakan dengan baik. Setiap tahapan dalam pengelolaan dana desa sudah dilaksanakan sesuai dengan Peraturan Menteri Dalam Negeri Nomor 113 tahun 2014 tentang Pengelolaan Keuangan Desa dan tidak ditemukan potensi fraud dalam pengelolaan dana desa karena 
adanya penerapan strategi yang dilakukan untuk mengurangi risiko potensi fraud. Strategi yang diterapkan di Desa Karangtengah untuk mengurangi risiko potensi fraud diantaranya adalah pengawasan yang dilakukan oleh pihak-pihak terkait, penerapan siskeudes yang membuat pencatatan transaksi keuangan lebih tertata dan adanya kesadaran dari aparat desa untuk tidak menyelewengkan dana desa karena menganggap dana tersebut adalah milik masyarakat yang harus digunakan dengan sebaik-baiknya serta adanya partisipasi masyarakat dalam pengelolaan dana desa. Saran untuk penelitian selanjutnya adalah menambah narasumber agar lebih mewakili semua komponen.

\section{Daftar Rujukan}

Agusta, I,"Teknik Pengumpulan dan Analisis Data Kualitatif", Jurnal Studi Komunikasi Dan Media, 02(1998), 1-11, 2014.

Arens, Elder. B," Auditing and assurance services",Orbit An International Journal On Orbital Disorders And Facial Reconstructive Surgery. https://doi.org/10.1016/0005-1098(86)90018-X, 2014.

Atmadja, A. T., Adi, K., \& Saputra. K,"Pencegahan fraud dalam pengelolaan keuangan desa" 1, 7-16, 2015.

Larony Tangkaroro, K., Ilat, V., Wokas, H., Akuntansi, J., Ekonomi dan Bisnis, F., Sam Ratulangi, U., \& Kampus Bahu, J., "Penerapan Sistem Dan Prosedur Akuntansi Pengelolaan Dana Desa Di Desa Tincep Kecamatan Sonder Kabupaten Minahasa", Jurnal Riset Akuntansi Going Concern (Vol. 12), 2017.

Pemerintah Republik Indonesia, Permendagri nomor 113 tahun 2014, Respiration Physiology, 61(2), 255264. https://doi.org/10.1016/0034-5687(85)90130-6, (2014).

Pemerintah Republik, \& Indonesia, UU No.6 Tahun 2014 Tentang Desa, (1), 103. Retrieved from http://www.dpr.go.id/dokjdih/document/uu/UU_2014_6.pdf, (2014).

Putri, A. (2012). Kajian : Fraud ( Kecurangan ) Laporan Keuangan.

Rizqyana Amanda, Dana Desa di Kabupaten Semarang untuk Tahun 2018 Mengalami Penurunan Artikel ini telah tayang di Tribunjateng.com dengan judul Dana Desa di Kabupaten Semarang untuk Tahun 2018 Mengalami Penurunan. TribunJateng.Com. Retrieved from http://jateng.tribunnews.com/2018/01/23/dana-desa-di-kabupaten-semarang-untuk-tahun2018-mengalami-penurunan, (2018).

Seputro, H. Y., Wahyuningsih, S. D., \& Sunrowiyati, S,"Potensi fraud dan strategi anti fraud pengelolaan keuangan desa",Jurnal Penelitian Teori Dan Terapan Akuntansi, 2(1), 79-93, 2017.

Simbolon, H. A. (2010). Mengupas seluk beluk fraud dan cara mengatasinya.

Susanto, B., Kasus penyelewengan dan desa, kajari Pamekasan dituntut 5 tahun bui. Https://Www.Merdeka.Com/Peristiwa/Kasus-Penyelewengan-Dana-Desa-Kajari-PamekasanDituntut-5-Tahun-Bui.Html, (2017).

Tanjung, C. A, Kasus korupsi dana desa, kades di Riau dituntut 5 tahun penjara. Https://News.Detik.Com/Berita/d-3746758/Kasus-Korupsi-Dana-Desa-Kades-Di-Riau-Dituntut-5Tahun-Penjara, (2017).

Trihargo,G,"Survei fraud indonesia", ACFE,13, 2016.

Wibisono, N., \& Purnomo, H. (2017). Mengungkap Fenomena Pengawas Publik Terhadap Dana Desa di Kabupaten Madiun. Akuntansi Dan Sistem Informasi, 2(1), 8-19.

Widayat, B, Korupsi dana desa, kepala desa di Mojokerto dijebloskan ke penjara. Https://Www.Merdeka.Com/Peristiwa/Korupsi-Dana-Desa-Kepala-Desa-Di-Mojokerto-DijebloskanKe-Penjara.Html, (2018). 